\title{
THE CONTROL OF OUTDOOR ADVERTISING, AMENITY AND URBAN GOVERNANCE IN BRITAIN, 1893-1962*
}

\begin{abstract}
This article examines approaches to the control of outdoor advertising in Britain, principally focused upon the first half of the twentieth century. It evidences both a radical change in the urban environment that has gone largely unexplored by historians, but also functions as a lens through which we might examine the motivations and importance of local government in driving physical change. The article argues that, despite important early work by elite preservationist organisations, local corporations and councils were the principal drivers of legislation and altered attitudes in central government towards control of urban outdoor advertising. Beginning in the nineteenth century, but coming to the fore during the interwar period, corporations and councils pushed for ever greater controls over the size and siting of billboards, hoardings and posters. In doing so they deployed a language of amenity, and conjured with seemingly social democratic notions of citizens' rights to push their agenda. The study is thus revealing of the ways in which town planning, patterns of holistic control in the visual environment, and the philosophy of urban modernism shaped even the most mundane, extant urban areas and left a lasting impression on the urban landscape.
\end{abstract}

In February 1960, during a debate concerning outdoor advertising legislation, Labour MP,

Francis Noel-Baker told The Commons:

I agree unreservedly with bodies such as the Council for the Preservation of Rural England which believe that, with the exception of indispensable public notices and signs on business premises, all outdoor advertising is a vulgar and impertinent intrusion upon the individual citizen and that it is inherently objectionable ... Outdoor advertising by garish posters, whether illuminated or not, is always incongruous and, therefore, injurious to the surroundings in which the posters are placed. ${ }^{1}$

Though few MPs were as vehement as Noel-Baker, he typified the prevailing view in both central and local government: that outdoor advertising was not simply injurious to Britain's beautiful or historic landscapes, but that its very presence was invariably deleterious to inhabitants' experience of all urban environments. This position was not simply an objection to poor advertising practices, nor a mere matter of taste. Indeed, much had been done by advertisers to standardise billboard sites, eliminate fly-postering, and to voluntarily regulate

\footnotetext{
Author address and email author@uniof.com

* The author would like to thank...

${ }^{1}$ Hansard, HC Deb, 29 Feb 1960, vol.618, cc.967-90.
} 
the industry since the mid-nineteenth century. ${ }^{2}$ Instead, what Noel-Baker's words betokened was a shift in the way philosophies of governance imagined the relationship between the urban environment and citizens' experience that had a profound and lasting impact on how towns and cities looked.

This attitude towards billboards, posters and other commercial signage had, however, only recently found acceptance in government. In the preceding century, and despite increasing restrictions after 1907 on advertising in rural and historic locations, introducing legislative controls in most urban areas, particularly residential neighbourhoods had been frustrated by objections from within parliament and the powerful lobbying of the advertising industry. ${ }^{3}$ Yet, beginning with the 1947 Town and Country Planning Act (T\&CPA), the postwar period witnessed the rapid introduction of substantially enhanced local government powers and signalled a change in attitude within central government. As a result, by the time the 1962 T\&CPA cemented powers to reduce the size and number of signs outside business premises, local authorities had drastically reduced advertising and commercial signage on their streets, radically and permanently altering the visual environment of urban Britain.

The mechanisms by which this change to towns and cities occurred though, have received relatively little attention. Advertising as a practice has interested historians because its development since the mid-nineteenth century symbolises consumer capitalism's growing ability to insert itself into the fabric of people's lives. ${ }^{4}$ Indeed, this commercialisation of the everyday was highly visible in the collection of hoardings, postered dead walls and gable-

\footnotetext{
${ }^{2}$ See: Ernest Sackville Turner, The shocking history of advertising (Harmondsworth, 1965), pp. 249-51

3 The Advertisements Regulation Bills of 1913, 1919, 1920 and 1921 were defeated before their second readings whilst the revised bill, passed in 1925, only curtailed advertising in rural and historic settings. Denys Thomson, Voice of civilisation: an enquiry into advertising (London, 1943), p. 182; Advertisements Regulation Act (ARA), 1925, (15 \& 16 Geo. 5. c.52), section 1 (1-3) for specific provisions. Also: Cyril Sheldon, A history of poster advertising (London, 1937), pp. 147-78.

${ }^{4}$ Stuart Ewen, Captains of consciousness: advertising and the social roots of consumer culture (New York, 1976); Matthew Hilton, Consumerism in twentieth-century Britain (Cambridge, 2003), particularly ch.7; Sean Nixon, Hard sell: advertising, affluence and transatlantic relations, c.1951-69 (Manchester, 2013); Clemens Wischermann and Elliott Shore, eds., Advertising and the European city: historical perspectives (Aldershot, 2000).
} 
end signs [Figs. 1-3] that characterised early-twentieth-century streetscapes. Nevertheless, debates in the existing scholarship tend to revolve around the content and techniques of advertising, whilst questions about control deal with the regulation of manufacturers' claims rather than the medium itself. ${ }^{5}$ Studies that have examined outdoor advertising as a physical phenomenon have either focused on emblematic nineteenth-century European cities, confined their scope to the United States, or considered the faded remnants of so-called 'ghost signs' ${ }^{6}$ Where histories of Britain have touched upon outdoor advertising control, they say little about activism that did not come from the preservationist campaign groups that formed in the late-nineteenth century, whilst histories from the advertisers' perspectives have tended to largely narrate the story as one of self-regulation. ${ }^{7}$

Advertising control in urban spaces either side of the Second World War was, however, not simply a response to the aesthetic displeasure of architectural protectionists. As the opening section of this article argues, though dominating the initial discussions of outdoor advertising control, preservationists' interest in urban environments typically extended only to the picturesque, architecturally outstanding or the historically valuable. ${ }^{8}$ Nor was

\footnotetext{
${ }^{5}$ W. Hamish Fraser, The coming of the mass market (London, 1981), pp. 134-46; Frank Mort, 'The commercial domain: advertising and the cultural management of demand', in Becky Conekin, Frank Mort and Chris Waters, eds., Moments of modernity: reconstructing Britain, 1945-1964 (London, 1999), pp. 55-75.

${ }^{6}$ On nineteenth-century cities: Nicholas Daly, The Demographic Imagination and the Nineteenth-Century City: Paris, London, New York (Cambridge, 2015), pp. 107-47; Thomas Richards, The commodity culture of Victorian England: advertising and spectacle, 1851-1914 (Stanford, 1990); Aaron J. Segal, 'Commercial immanence: the poster and urban territory in nineteenth-century France', in Wischermann and Shore, eds., Advertising and the European city, pp.113-38. On the USA: John W. Houck, ed., Outdoor advertising: history and regulation (London, 1969); Charles R. Taylor and Weih Chang, 'The history of outdoor advertising regulation in the United States', Journal of Macromarketing, 15:1 (1995), p.47-59. On ghost signs: Stefan Schutt, Sam Roberts and Leanne White, eds., Advertising and public memory: social, cultural and historical perspectives and ghost signs (Abingdon, 2017).

${ }^{7}$ Anne M. Cronin, Advertising myths: the strange half-lives and images of commodities (London, 2004), pp.345; Turner, The shocking history of advertising. The exceptions to the prevailing narrative are two books by former advertising industry professionals Terry Nevett, Advertising in Britain: A History (London, 1982) - a book produced on behalf of the advertising industry's own History of Advertising Trust - and Sheldon, $A$ History of Poster Advertising who both present the introduction of advertising controls as largely the product of a responsible and civic-minded advertising industry.

8 John Hewitt, 'The 'nature' and 'art' of Shell advertising in the early 1930s', Journal of Design History, 5:2 (1992), pp. 121-39; David Matless, Landscape and Englishness (London, 1998), pp. 25-35, 47-52; Paul Readman, 'Landscape Preservation, "advertising disfigurement”, and English National Identity c.1890-1914, Rural History, 12:1 (2001), pp. 61-83.
} 
opposition to outdoor advertising merely conservative anti-modernity. As James Taylor's study of opposition to 'sky signs' has also shown, control of outdoor advertising was about accommodating a vital economic function, whilst placing limits on the spaces and lives into which commercial interests might encroach. ${ }^{9}$ Indeed, Peter Gurney has demonstrated that the only evidence of a concerted attack on advertising as a matter of principle was by the postwar Labour government, a campaign that lasted barely two years. ${ }^{10}$

This article shows how this striking change in the visual environment of cities and towns was in large part driven by local authorities' developing municipal concerns, framed within their broader strategies and philosophies of urban governance and developing over a century. Issues such as rateable value, street clutter, the commercialisation of residential space and citizens' rights, emerge as key issues in attempts to regulate outdoor advertising. Yet, these were facets of the wider practices that might generally fall into that 'oxymoronic formulation' liberal governmentality. ${ }^{11}$ In the earliest examples, examined in section three, outdoor advertisements represented a physical impediment to attempts to create regimes of free movement and self-control, whilst in the mid-twentieth century they disrupted the efficacy of corporations' schemes of planned redevelopment. ${ }^{12}$ The study thus address arguments over the decline in local government by showing - as Tom Hulme has in the context of interwar civic pride - an energetic, sometimes over-adventurous local state, pushing the boundaries of their powers either side of the Second World War. ${ }^{13}$ Indeed, in

\footnotetext{
9 James Taylor, 'Written in the skies: advertising, technology and modernity in Britain since 1885', Journal of British Studies, 55:4 (2016), pp. 750-80.

${ }^{10}$ Peter Gurney, 'Voice of Civilisation: advertising and its critics in austerity Britain', Contemporary British History 32:2 (2018), pp.190-208.

${ }^{11}$ Patrick Joyce, The rule of freedom: liberalism and the modern city (London, 2003), p.259. Joyce favours the term 'liberal governance'.

12 Joyce, The rule of freedom, p.86-88.

${ }^{13}$ On the post-war resurgence see: Nick Hayes, Consensus and Controversy: City Politics in Nottingham 194566 (Liverpool, 1996); Ken Young and Nirmala Rao, Local Government since 1945 (Oxford, 1997). On the interwar see John Sheldrake, Municipal Socialism (Avebury, 1989); and earlier: Simon Gunn, The public culture of the Victorian middle class: ritual and authority in the English industrial city, 1840-1914 (Manchester, 2000), 187-97.
} 
tracing the character of local government interventions the article stresses the development of advertising control within regimes of urban governance that sought to civilise and shape citizens through the control of the sensory environment. ${ }^{14}$ Moreover, by showing how strategies of regulation were subsequently recast within the language and ideology of midtwentieth century planning, the article plots advertising control as one highly visible point on the trajectory of urban modernism in mid-twentieth century Britain. ${ }^{15}$

Outdoor advertising was anathema to planners and architects because they believed its very presence disrupted the civilising influence of planned architectural display and thus the socio-spatial objectives of redevelopment plans. ${ }^{16}$ Yet, the evidence presented in the fourth and fifth sections of this article shows post-war corporations pushing for powers to control advertising in both newly built and extant locations. During a period when advertisers naturally attempted to utilise unoccupied patches of land or gable ends, local corporations consistently opposed advertising hoardings in any residential area. This study understands the corporations' attempts to be part of the quietly radical set of practices that historians like Simon Gunn have termed, 'urban modernism'. ${ }^{17}$ Urban modernism, though often linked with architectural Modernism as a style, was characterised by the holistic regulation and redevelopment of towns and cities, and a belief that a the management and production of urban space through a sort of 'technocratic pragmatism' might produce more functional cities

\footnotetext{
${ }^{14}$ Leif Jerram, Streetlife: the untold story of Europe's twentieth century (Oxford, 2010); Joyce, The rule of freedom; Chris Otter, 'Making liberalism durable: vision and civility in the late Victorian city', Social History, $27: 1$ (2002), pp. 1-15.

${ }^{15}$ On urban modernism and aesthetic Modernism as aspects of post-war government see: Nicholas Bullock, Building the post-war world: modern architecture and reconstruction in Britain (London, 2002); John Gold, The experience of modernism: modern architects and the future city, 1928-53 (London, 1997); Simon Gunn, 'The rise and fall of British urban modernism: planning Bradford, circa 1945-1970', The Journal of British Studies, 49:4 (2010), pp. 849-69; Christopher Klemek, The transatlantic collapse of urban renewal: postwar urbanism from New York to Berlin (Chicago, 2011).

${ }^{16}$ Laura Baker, 'Public sites versus public sights: the progressive response to outdoor advertising and the commercialization of public space', American Quarterly, 59:4 (2007), pp. 1187-213; Kurt Iveson, 'Branded cities: outdoor advertising, urban governance, and the outdoor media landscape', Antipode, 44:1 (2012), pp. 151-74.

${ }^{17}$ For further definition of urban modernism see section five of this article and: Gunn, 'The rise and fall of British urban modernism'; Otto Saumarez Smith, 'The inner city crisis and the end of urban modernism in 1970s Britain', Twentieth Century British History, 27:4 (2016), pp. 578-98.
} 
and healthier, happier inhabitants. ${ }^{18}$ Here, this tendency is represented by an impulse to control and reorder the visual environment and a belief in the efficacy of such order, not the sporadic grand architectural schemes associated with architectural Modernism. What this emphasis on controlling advertising in all locations reveals is that urban governance in the mid-twentieth century increasingly meant imagining how citizens' experience of everyday environments could produce, as Lucy Faire an Denise McHugh have argued, a sense of place and belonging in the city. ${ }^{19}$ This was not just, as Selina Todd has demonstrated, a facet of civic design, but expanded into the quotidian and, crucially, extant spaces of everyday life. ${ }^{20}$ The article thus provides a self-contained explanation of how such a startling visual change occurred in urban spaces, but also functions as a case study that examines the ways that urban governance in twentieth century Britain came to place the experience of the citizen at the heart of philosophies of redevelopment and renewal.

\section{II}

Although, as advertising writer David Bernstein observed, 'advertising began outdoors', new printing techniques and the emerging mass market meant that throughout the nineteenth century large-size billboard advertising exploded in popularity, ultimately superseding bill postering as the dominant form of outdoor advertising shortly after the First World War. ${ }^{21}$ Advertisers, though they had begun to practice forms of self-regulation since the midnineteenth century, were 'scarcely restricted by legislation', whilst simultaneously driven to expand by a competitive market place. ${ }^{22}$ Consequently, throughout the early part of the

\footnotetext{
${ }^{18}$ On the distinction between urban modernism and Modernist architecture, and the character or urban modernism as a phenomenon either side of the Second World War, see: James Greenhalgh, Reconstructing Modernity: space, power and governance in mid-twentieth century British cities (Manchester, 2017), pp. 11-2.

${ }^{19}$ Lucy Faire and Denise McHugh, 'Twelve shades of grey: encountering urban colour in the street in British provincial towns, c. 1945-1970', Urban History, 46:2 (2019), pp.288-308.

${ }^{20}$ Selina Todd, 'Phoenix rising: working-class life and urban reconstruction, c. 1945-1967', Journal of British Studies, 54:3 (2015), pp. 679-702.

${ }^{21}$ David Bernstein, Advertising outdoors: watch this space! (London, 1997), p. 12; Fraser, The coming of the mass market, pp. 135-8.

${ }^{22}$ Turner, The shocking history of advertising, p. 132; Raymond Williams, 'Advertising: the magic system' in Problems in Materialism and Culture (London, 1980), pp. 170-195.
} 
twentieth century streets in towns and city centres, along with most railway sidings typically sported a variety of hoardings and billboards [see: Figs. 1-3]. Adding to these displays, shop fronts, dead walls and gable ends bore the brand names and logos of famous products that grew larger and more eye-catching with each passing year. ${ }^{23}$ At the same time the growing production of incandescent and neon lighting allowed advertisers to create nocturnal vistas of consumerism. ${ }^{24}$

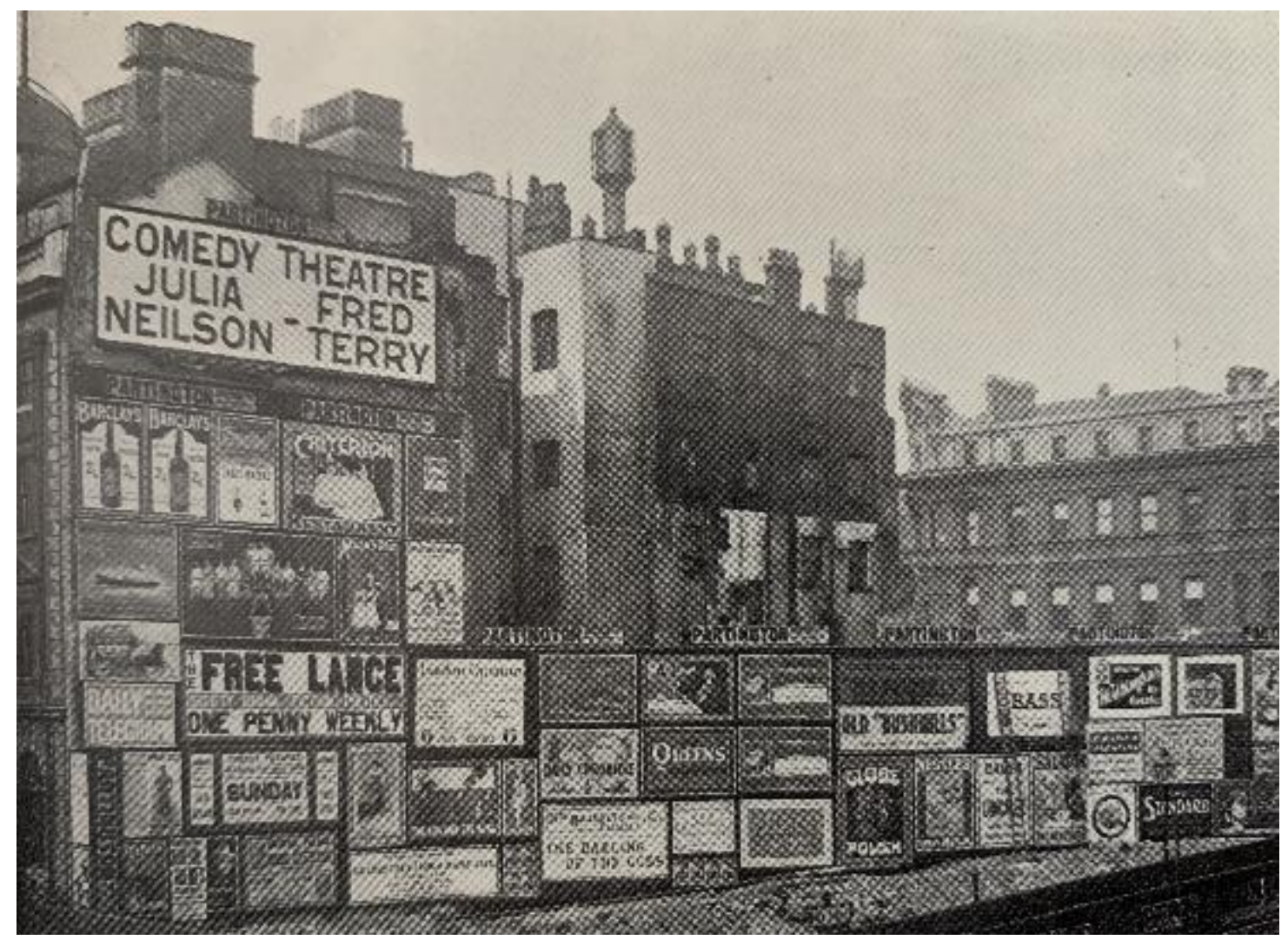

Figure 1: Advertising station, London, c.1905. From Clarence Moran, The business of advertising (London, 1905), plate opposite p. 162.

\footnotetext{
23 Turner, The shocking history of advertising, pp. 242-50.

${ }^{24}$ On technological advances in lighting and their impact upon the nature of urban space see: Anne M. Cronin, 'Advertising and the metabolism of the city: urban space, commodity rhythms', Environment and Planning D: Society and Space, 24 (2006), pp. 615-32; Wolfgang Schivelbusch, (trans. Angela Davies), Disenchanted night: the industrialisation of light in the nineteenth century (Exeter, 1988).
} 


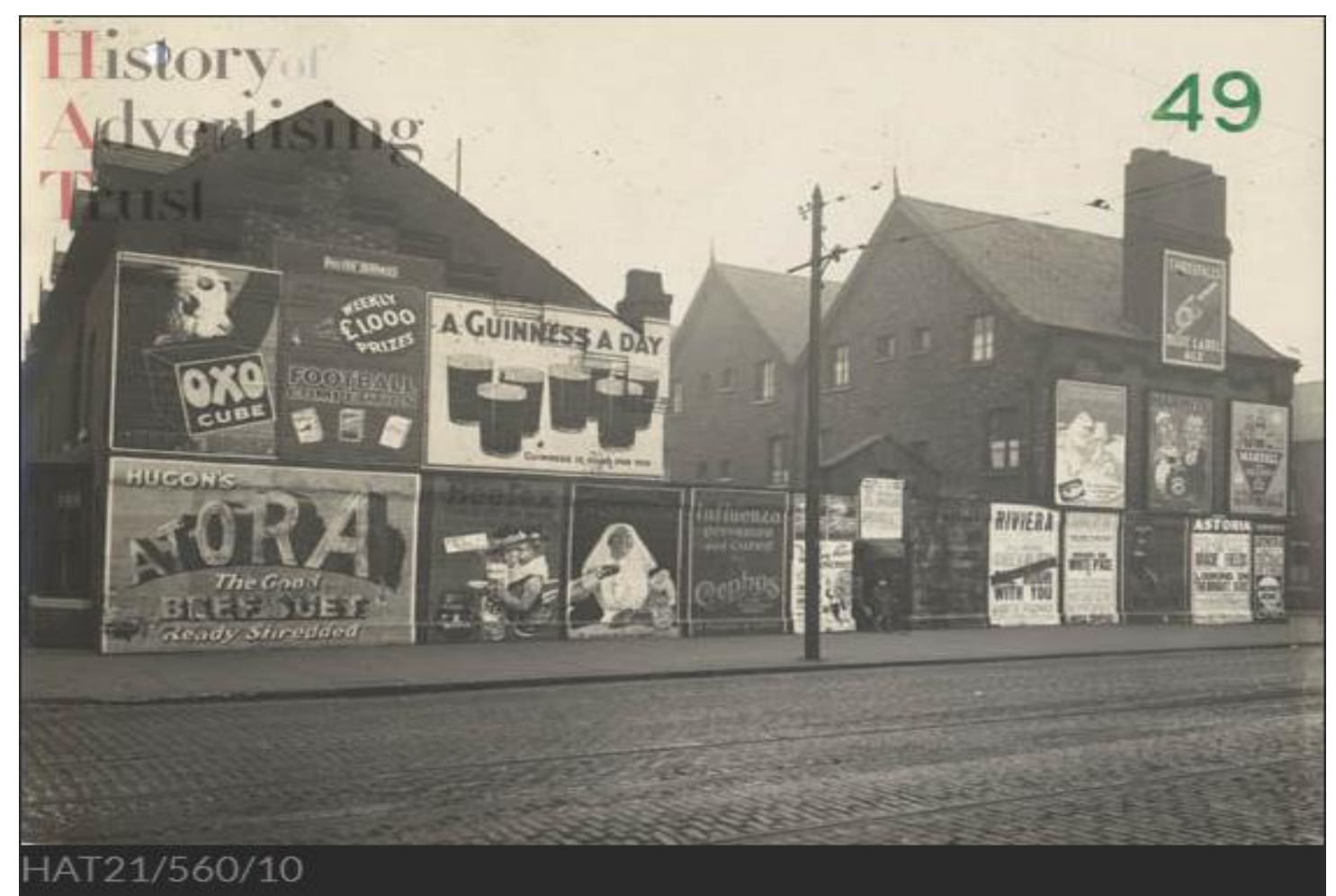

Figure 2. Advertising on Leicester Road, Higher Broughton, Lancashire early 1930s, reproduced with the permission of the History of Advertising Trust (HAT), archive 21/560/10. 


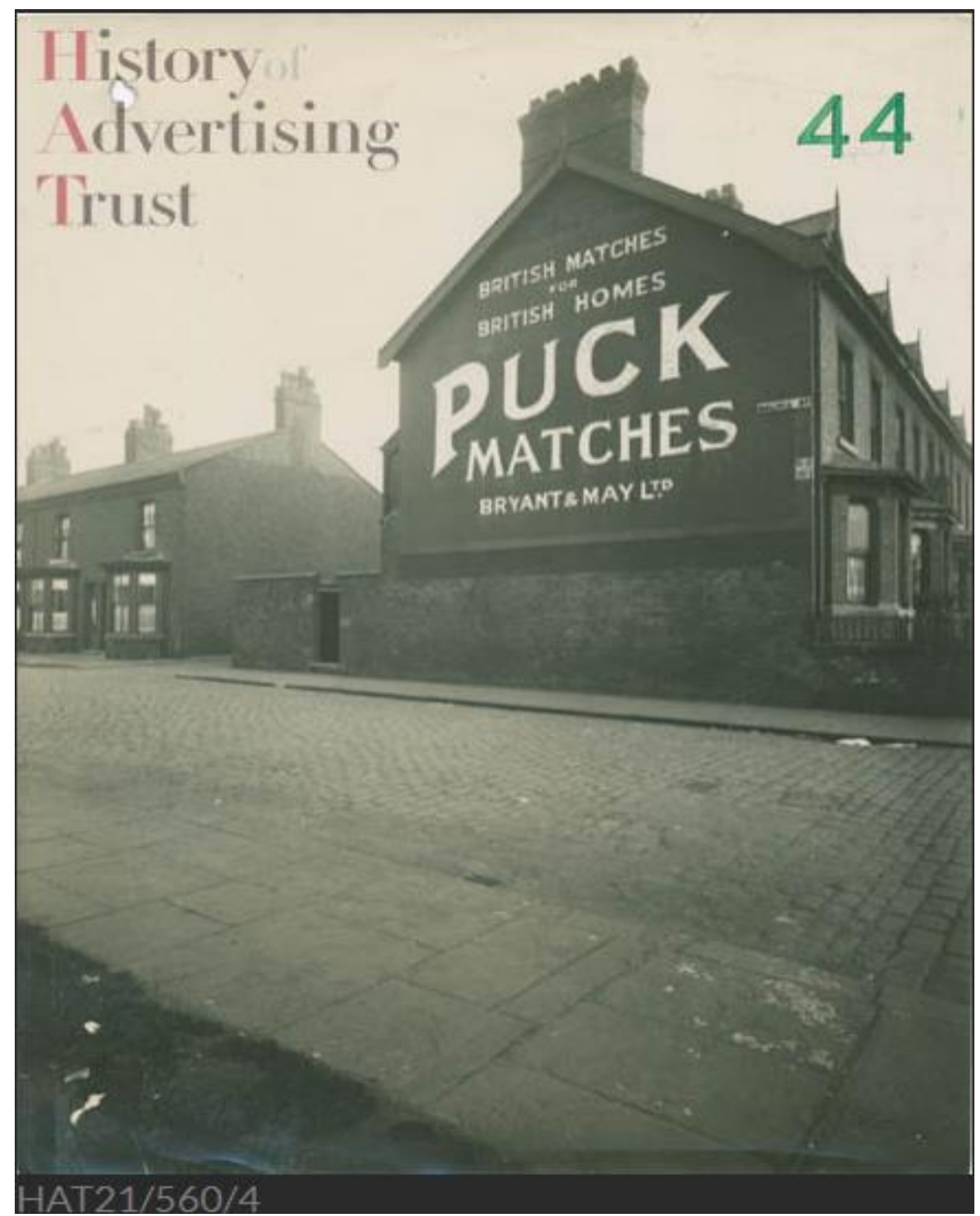

Figure 3. Gable end advertisement, Eccles New Road, Pendleton, Lancashire, early 1930s, reproduced with the permission of the HAT, archive 21/560/4.

Advertisers in the first half of the twentieth century, nevertheless, argued that outdoor advertising could be beneficial. W.T Stead's assertion that 'the picture gallery of the English poor is the hoardings of the street' and Franck Pick's belief that modern art on London Underground advertising might open up the possibilities of the city to travellers, illustrate the 
common view that tastefully rendered billboards were something of a boon. ${ }^{25}$ Indeed, having done much to standardise practice and curtail the more egregious activities of bill-posters, they received some high profile support. ${ }^{26}$ Oscar Wilde reputedly arguing that 'they bring colour into the drab monotony of the English streets' ${ }^{27}$ Nevertheless, opposition to outdoor advertising had begun to crystallise towards the end of the nineteenth century as larger and more intrusive forms of advertising caused conflict with local authorities. Bovril's attempts to erect billboards near historic properties in Edinburgh led to local protests and the subsequent inclusion of powers to licence outdoor advertising in the Edinburgh Corporation Act $1899 .^{28}$ In 1900, in what was perhaps the nadir of the advertising arms race, Quaker Oats placed a huge advertisement on the cliffs at Dover [Figure 4] provoking a considerable backlash from the local authority and newspapers. Such brash advertising excess in a location so tied-up with English identity prompted a national campaign, which led directly to the creation of strict local powers to curtail advertising hoardings in the Dover Corporation Act, 1901.29

\footnotetext{
${ }^{25}$ William T. Stead, The art of advertising. Its theory and practice fully described (London, 1899), often repeated as 'the poor man's picture gallery', see: Hansard, HC Deb, 28 Feb 1930, vol.23, c. 2594; Michael T.Saler, The avant-garde in interwar England: medieval modernism and the London Underground ((Oxford, 1999), pp. 99-101.

${ }^{26}$ Sheldon, History of poster advertising

${ }^{27}$ This quote appears in Blanche Elliott, A History of English Advertising (London, 1962), p. 165, but is unattributed. Apocryphal or not, it serves to illustrate the perception of support.

${ }^{28}$ Clauses 45 and 48, Edinburgh Corporation Act 1899, see: 'Local Authorities Scotland', London Metropolitan Archives (LMA)/GB0074/A/SCA/03/002/025.

29 'Correspondence with Local Authorities, D', 19 June 1911, LMA/A/SCA/03/002/007. Also: John McDonough and Karen Egolf, The advertising age encyclopaedia of advertising (London, 2002), unpaginated electronic copy; Moran, The business of advertising, p. 176; Readman, 'Landscape Preservation, "advertising disfigurement", pp. 67-8.
} 


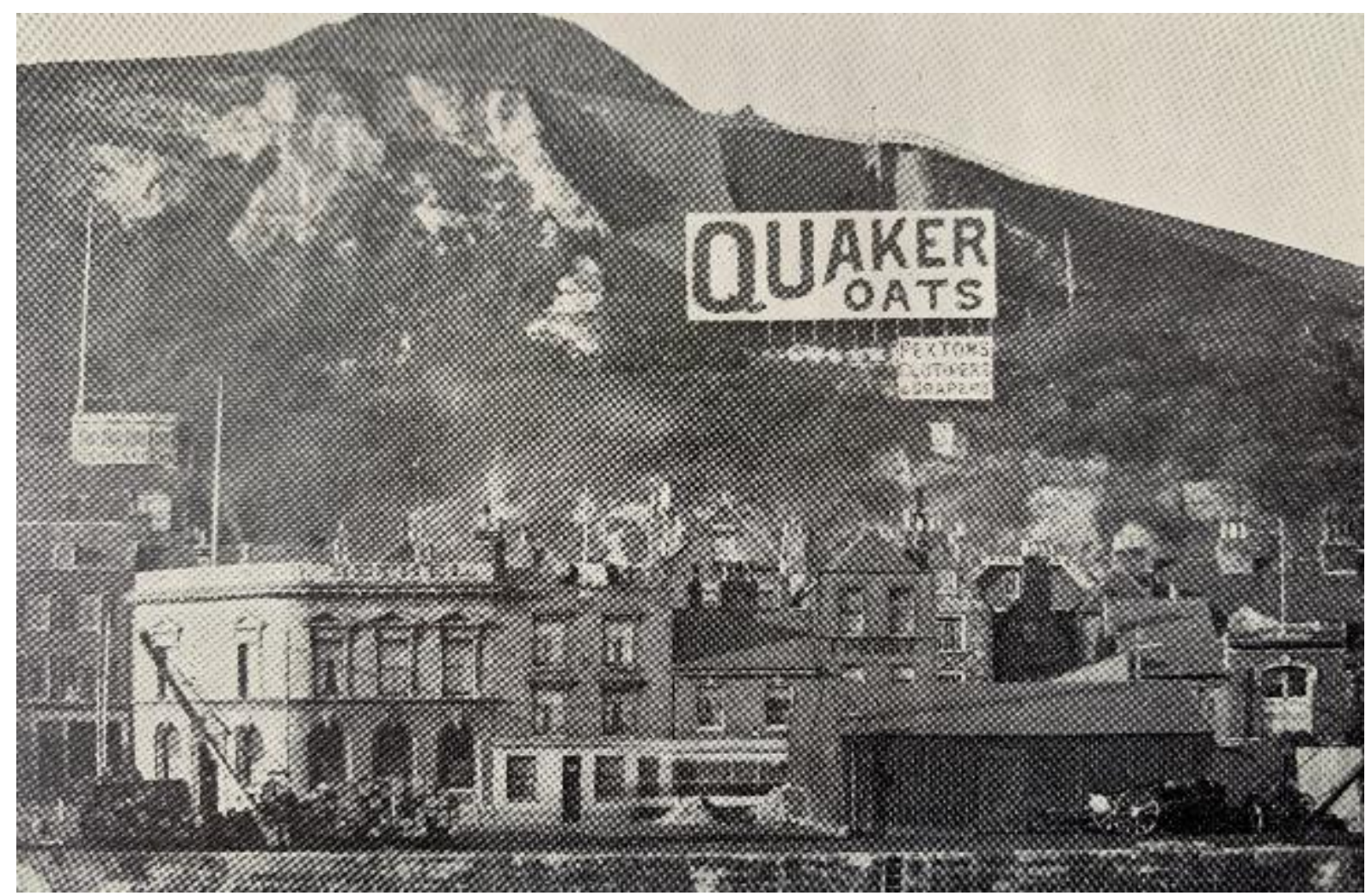

Figure 4: A Quaker Oats advertisement at Dover, 1900. From Moran, The business of advertising, plate opposite p. 171.

Instrumental in these campaigns were the Society for Checking Abuses of Public Advertising (SCAPA), a preservationist organisation who viewed advertisements as a 'social malady' that negated the cultural value of beautiful landscapes and picturesque towns. ${ }^{30}$ Founded in 1893, SCAPA's principle objective was to oppose 'disfigurement in town and country' and 'to purge the streets and country ways, the fields and riverbanks' of advertisements. ${ }^{31}$ Though they had a small membership of around 700 and were opposed to attracting mass membership, SCAPA represented a growing, remarkably influential elite backlash against outdoor advertising. ${ }^{32}$ Despite any clear indication of mass support, in their first few decades SCAPA exerted enough influence within powerful circles to enjoy a string of successes, particularly in the prevention of advertising that 'disfigure[d] the natural beauty

\footnotetext{
${ }^{30}$ Richardson Evans, An account of the SCAPA society (Glasgow, 1926), p. 138.

31 'The Advertising Plague', Times, Richardson Evans, 18 Nov 1892, p. 12 \& repeated multiple times in general purposes of the society in LMA/GB0074/A/SCA 01 \& 02, Society for Checking Abuses of Public Advertising, 1892-1952 archive. SCAPA would later expand their campaigns to littering.

32 In June 1894 SCAPA's Beautiful World journal claimed membership was at 730: A beautiful world: the journal of the Society for Checking the Abuses of Public advertising, 3 (1894), p.121.
} 
of the landscape'. ${ }^{33}$ Highly visible victories and a great deal of media support for the protection of the countryside had garnered a sufficient profile that by 1905 only two large advertising firms still saw benefit in erecting rural billboards at all. ${ }^{34}$ Indeed, by 1913 all major tyre manufacturers had agreed to remove roadside advertisements and by 1927 Shell Oil - once one of the most significant investors in roadside advertisements - announced it would remove all signs except those at filling stations. ${ }^{35}$ The perceptions of advertisers and their customers point to a degree of public support for SCAPAs attempts to eliminate advertising in the countryside that was likely crucial. Indeed, in a 1938 Mass Observation survey most of the very few objections to outdoor advertising were on the grounds that it disfigured the countryside. In contrast only one female respondent objected to in urban environments, stating that 'I often wish to go away from London because of the advertising one sees everywhere. Words, words, everywhere. I wish there were as many flowers as words in London' ${ }^{36}$ Even where newspaper coverage can be found, nothing suggests they had a groundswell of public backing, and supportive letters were often from registered members. ${ }^{37}$

In the same period, SCAPA also promoted bills through parliament on an almost yearly basis. In 1907, after three previous attempts had been opposed by outdoor advertisers, the SCAPA-sponsored Advertisements Regulation Act (ARA) was passed, allowing the creation of local byelaws to designate particular areas of aesthetic value in which advertisements could be restricted to preserve 'amenity. ${ }^{38}$ In the decades that followed,

\footnotetext{
${ }^{33}$ Evans, An account of the SCAPA society, p. 364.

${ }^{34}$ Moran, The business of advertising, p. 121.

35 'Letter from Michelin to SCAPA', 23 Jul 1913, LMA/GB0074/A/SCA/03/009/009; Nevett, Advertising in Britain, p. 161. Shell's change of heart was also due to the realisation that they could advertise on delivery vans. Malcolm V. Speakman, Shell's England: corporate patronage and English art in Shell posters of the 1930s, (PhD Thesis, University of Manchester 2014), ch.2, passim.

${ }^{36}$ Mass Observation Archive (MOA), 22-1-A, 'Typed Reaction to Advertising', in Reactions to Advertising, Dec 1938, pp.19-21.

${ }^{37}$ Readman, "Landscape Preservation, "advertising disfigurement".

${ }^{38}$ Advertisements Regulation Act, 1907 (7 Edw. 7. c.27). See also: Evans, An account of the SCAPA society, pp. 80-4; Sheldon, History of poster advertising, pp. 168-71. This was not the first time the term amenity had been used, but it was the first time it had been used in relation to preservation of a certain character, rather than as a term to describe general pleasantness.
} 
'amenity' and its interpretation would become central to contests surrounding outdoor advertising, but the 1907 act proved to be weak in its definitions and, consequently, of only sporadic popularity with local authorities. Throughout the first three decades of the century SCAPA continued to lobby for further extensions of the Act (new bills being defeated twice in 1913), pushed sluggish local authorities to make byelaws and continued a correspondence with the Exchequer over the potential introduction of taxation for posters and billboards. ${ }^{39}$ SCAPA were ultimately instrumental in the passage of the 1925 ARA, which strengthened the definitions contained in section two of the 1907 Act to clearly include scenic elements of roads, rail or waterways, all villages as well as historic buildings and urban areas of outstanding beauty. ${ }^{40}$

The collection of powers to control outdoor advertising, however, had little capacity for the protection of residential, commercial or industrial areas of towns and cities. Indeed, this was never the aim of preservationists, who viewed 'amenity' as a quality exclusively derived from judgements about exceptional beauty, pleasantness or historical worth. SCAPA's agenda thus remained focused upon landscapes and buildings that they believed encapsulated, in both aesthetic and historical terms, a valuable continuity of Englishness and national identity that more mundane urban spaces could not. ${ }^{41}$ Objecting to advertising near Westminster Abbey in his foundational essay of 1890 'The Age of Disfigurement', SCAPA's honorary secretary and driving force Richardson Evans wrote:

It is surely and affront to practical intelligence that a spot dominated by a church dear to all men of English blood, consecrated by history as well as religion, and in architectural glory of supreme excellence, should be exposed, as it now is, to the profanation of glaringly sordid surroundings.

\footnotetext{
${ }^{39}$ There is voluminous correspondence with multiple local authorities in the SCAPA files pushing them to make byelaws, with mixed success, see: LMA GB0074 A/SCA/03/002/001-30. On the 1913 amendments: 'SCAPA Pamphlets -No.3', Jan 1913 \& 'Letter to Sir George Younger', 22 Apr 1913, LMA/GB0074/A/SCA/03/09/013. On taxation: 'Committee Minutes', 18 Oct 1912, LMA/GBA0074/A/SCA/01/001.

${ }^{40}$ ARA, 1925, s.1 (1a-c). On SCAPA’s role see: Hansard, HL Deb, 4 Mar 1924, vol. 56, cc.477-81.

${ }^{41}$ Matless, Landscape and Englishness; Readman, 'Landscape preservation'.
} 
SCAPA were, then, not crudely anti-urban, nor simplistically concerned with the preservation of a particular historical period or architectural style. Indeed, Evans put much time and effort into preserving areas of south London around his home in Wimbledon, commenting that, whilst nearly all recognised the need to preserve the countryside, too many were ready to condemn the city as inherently ugly. ${ }^{42}$ SCAPA's manifesto too made it clear that the objectives of the society were 'To protect [both] the picturesque simplicity of rural and river scenery [and] to promote a regard for dignity and propriety of aspect in towns - with especial reference to the abuses of spectacular advertising' ${ }^{43}$ Yet, guided by SCAPA, the 1925 ARA only protected the amenities of any area 'frequented by the public on account of its beauty or historic interest', which could include parks and exceptional residential areas. ${ }^{44}$

The collection of legislation enacted in the early decades of the century, coupled with a lesser concern for quotidian aspects of the built environment meant that by the early 1930s SCAPA had, in legislative terms at least, achieved much of what it set out to do. SCAPA's activism subsequently remained focused upon attempts to eliminate the small number of remaining signs on rural roads and on pressuring local authorities to use the 1925 ARA to object to advertisements that 'interfere[d] with natural beauty'. ${ }^{45}$ The association did continue until 1953, but with the death of the previously indefatigable Evans in 1928 and with their aims catered for in law, they showed little desire to extend their activism to the wider urban landscape. Though they would maintain a vocal presence in debates, by the postwar they were mostly a spent force whose objectives increasingly resembled those of their

\footnotetext{
${ }^{42}$ Richardson Evans, The age of disfigurement (London, 1893), pp. 60-1. On Evans' activism, see: 'Wimbledon and Malden, LMA/GB0047/A/SCA/03/002/029.

43 'SCAPA manifesto' c.1911, LMA/GBA0074/A/SCA/01/001.

${ }^{44}$ ARA, 1925, s.1(1c).

45 'Ugly signs and posters', Times, 8 Jan 1930, p. 8; 'The SCAPA society annual report', Times, 12 June 1931 , p. 13.
} 
counterparts like the Campaign to Protect Rural England. ${ }^{46}$ There is, though, little doubt that they had proved effective in promoting a subjective definition of how advertising should be controlled. Unlike the approaches covered in the following sections though, the laws that SCAPA had pushed to create left a system that had little power to control outdoor advertising in the great accumulation of everyday spaces, particularly residential areas, that made up so much of Britain's urban environment.

\section{III}

The drivers of change who picked up the baton from SCAPA were the local corporations and councils and, latterly, central government itself. Yet, by the 1930s outdoor advertising had been a concern to local governments for over a century. In contrast to SCAPA's focus, local authorities had shown increasing concern about how advertising might be regulated in all areas of cities as early as the first half of the nineteenth century. These initial forays into advertising control were usually elements of much larger municipal codes, that positioned outdoor advertising as a one of many material nuisances in bustling streetscapes. Provisions in London's 1817 Metropolitan Paving Act (extended in 1862) regulated obstructive advertising hoardings and the 1839 Metropolitan Police Act criminalised bill posting without consent. ${ }^{47}$ In 1844 Manchester reproduced similar laws, adding in prohibitions on the carrying of signs, boards and placards. ${ }^{48}$ The Towns Improvement Clauses Act, 1847 also followed these trends, allowing local authorities to remove advertising hoardings and signs that obstructed thoroughfares. ${ }^{49}$ Advertising control was thus symptomatic of wider emerging

\footnotetext{
${ }^{46}$ In 1951 SCAPA considered winding down and transferring funds and members to the Campaign for Rural England and there are no records of further meetings after 1952. 'Committee minutes', 21 Nov 1951, LMA/GB0047/A/SCA/01/004.

${ }^{47}$ Metropolitan Paving Act, 1817 (57 Geo. 3, c.29), s.75; Metropolis Management Amendment Act, 1862 (25 \& 26 Vict. c.102), s.73; Metropolitan Police Act, 1839, (2 \& 3 Vict. c.47), s.54 (10).

${ }^{48}$ Act for the Good Government and Police Regulation of the Borough of Manchester, 1844 (7 \& 8 Vict. c.40), s.60, $102 \& 282$.

49 The Towns Improvement Clauses Act, 1847 (10 \& 11 Vict. c.34), s.69.
} 
regimes of governmental regulation that anathematised anything that prevented free circulation in cities. ${ }^{50}$

Advertising regulation was as much about establishing general principles of control and order, as it was about any specific opposition to advertising per se. In 1871 Huddersfield Corporation obtained the power to fine anyone posting an advertisement or bill without the corporation's consent, a level of control that would seldom be attained by others before the middle of the following century. ${ }^{51}$ Chester and Carlisle are just two of several examples of local authorities who followed suit in 1884 and 1887, obtaining powers to create by-laws that allowed them to arbitrarily prohibit signs and advertisements in any location. ${ }^{52}$ Stemming from the London County Council's 1891 decision to ban 'sky signs' the Public Health Act 1907 gave local government the power to do likewise and three years later 154 local authorities in England and Wales had done just that ${ }^{53}$ Salford, as part of their 1899 Corporation Act, introduced a system that effectively gave them the ability to licence hoardings and posters, powers they would unsuccessfully seek to extend to cover all forms of outdoor advertising in $1933 .{ }^{54}$ Instances of total control, however, remained the rare exception. Other similar bills were systematically and successfully opposed by advertisers and sympathetic MPs, despite their considerable volume. Indeed, when former British Poster Advertising Association (BPAA) president Cyril Sheldon complied an incomplete list of all the local government acts the BPAA had opposed in parliament between 1900 and 1932, there were in excess of three hundred bills, nearly all of which had been substantially amended or defeated entirely. ${ }^{55}$

\footnotetext{
${ }^{50}$ Joyce, The Rule of Freedom, p. 88.

${ }^{51}$ Huddersfield Improvement Act, 1871 (34 \& 35 Vict. c.151), s.71 \& 232.

${ }^{52}$ Chester Improvement Act, 1884 (47 \& 48 Vict. c.239), s.146; Carlisle Corporation Act, 1887 (50 Vict. c.19), s.147.

53 Taylor, 'Written in the skies', p. 757.

${ }^{54}$ See: 'Byelaws: Salford: proposed advertisements byelaws, 1933-1938', National Archives (NA)/Housing and Local Government (HLG)/45/17523.

${ }^{55}$ Sheldon, A history of poster advertising, pp. 147-291.
} 
The early days of outdoor advertising control thus reflected the tendency of local authorities to develop increasingly cohesive systems of regulation and municipal codes. As authorities gradually exerted control over the physically intrusive aspects of poster and billboard advertising, there is little evidence that they, as yet, construed the mere presence of advertising as a threat to citizens' experience of the city. Corporations recognised that advertising stations, where positioned correctly, represented a profitable and necessary part of the spatio-economic function of their municipalities. It is unsurprising, then, that issues of taxation surrounding outdoor advertisements were a recurrent theme in the first half of the twentieth century. Preservationists like SCAPA saw direct taxation of advertisements by their size as both a method to increase revenue and deter their production, as was the case in France after $1911 .^{56}$ The 1901 Royal Commission on Local Taxation also concluded that 'another form of taxation which can properly be regarded as entirely local and which ought...to be freely put in operation at the option of Local Authorities, is the taxation of posters and similar advertisements' ${ }^{57}$

The Exchequer, however, proved deaf to calls for a tax on posters, whilst corporations and councils were instead more active in pushing for greater powers to tax advertisement stations (the common term for the boards or walls upon which they were mounted) through local rates. As historians of local government and taxation have shown, there has seldom been a period where local government was not animated by the desire to maximise rate revenues, but the first half of the twentieth century represented a particular moment of strain and reform in local taxation. ${ }^{58}$ Until 1889 Advertising Stations (Rating) Act, there were few ways that corporations could extract significant revenue from billboards, posters or hoardings

\footnotetext{
${ }^{56}$ Evans, The age of disfigurement, p. 21.

${ }^{57}$ Lord Balfour of Burleigh, Report of the Royal Commission on local taxation, 1901, C.D. 638, p. 71.

${ }^{58}$ See: Avner Offer, Property and politics, 1870-1914: landownership, law, ideology and urban development in England (Cambridge, 1981), ch.18 \& 21; Martin Daunton, Just taxes: the politics of taxation in Britain, 19141979 (Cambridge, 2002), ch.11.
} 
not displayed on their own land. Even when this act was passed, it was far from satisfactory to local government. Though it allowed a rateable value based on the amount an advertiser or advertising company paid to rent a hoarding or wall, it did not rate this separately from the parent hereditament. This meant that the occupier of, for example, a house with a billboard on the gable, was liable for the total rate for both the house as a dwelling and the value of the billboard. Properties that shared a wall or grounds complicated the situation further and had the overall effect of making it difficult to know what portion the rates assessment was levied upon the advertising station. ${ }^{59}$

Of course, this system confounded local government attempts to understand the unique value of the property as an advertising site, and sat uneasily with the impulse of local corporations to classify, rate and licence the spaces of their cities. In 1932, for example, the City of Plymouth wrote to urge the Ministry of Health to reconsider the legislation 'so as to remedy the present injustices of rating tenant occupiers of premises in respect of advertisement hoardings attached or adjacent thereto over which that have no control.' 60 Similarly in 1933 the Association of Municipal Corporations' (AMC) Rating and Assessment Committee recommended that the 1889 legislation should be amended to treat any land or structure used for advertising as a separate, rateable hereditament. ${ }^{61}$ As the LCC suggested in support of a private bill in 1931, the defects in the law were 'so serious, that in practice the law is not followed and the advertising stations are, as a rule, separately assessed. ${ }^{62}$ In addition where industrial premises had been derated or where advertisements were placed on agricultural land it often proved difficult to levy rates at all. Indeed, the Inland Revenue noted that revenue officers did not, as a matter of course, rate advertising stations on farm land,

\footnotetext{
${ }^{59}$ LCC letter to the Ministry of Health, 19 Jan 1931, NA HLG/56/1116.

60 'Resolution passed by the city council', 29 July 1932, NA/HLG/56/1116.

61 'Advertisement hoardings. Rating', 26 Oct 1933, NA/HLG/56/1116.

62 'LCC letter to the Ministry of Health', 19 Jan 1931, NA/HLG/56/1116.
} 
whilst advertising on railway land typically proved an unpassable legal quagmire. ${ }^{63}$ For local corporations, this was a practical issue of extracting value, but the records convey a more general unease at their inability to create delineated, categorised bodies of knowledge concerning this considerable presence in the urban landscape.

Local authorities and MPs pushed for change throughout the first half of the century, both by proposing byelaws or through the amendment of legislation like the 1925 Rating and Valuation Act, but made little progress. ${ }^{64}$ The 1932 LCC General Powers clause to separate hereditaments for occupancy and advertising, for example, floundered on opposition from the BPAA, who recognised that the clause would increase rates based on their profits. ${ }^{65}$ These proposed changes were, though, not a backdoor attempt to eliminate outdoor advertising. Indeed the above evidence instead suggests local government saw billboards and posters as a potentially valuable, inevitable part of the spatio-economic fabric of cities. Indeed, as central government priorities shifted in the 1950s towards reducing outdoor advertising, it became common for ministers to criticise local authorities for not going far enough to curtail billboards when the financial incentives were sufficiently large. ${ }^{66}$ Instead, attempts to rate and tax advertising stations, like earlier attempts to remove the physical disruption of billboards and posters, formed part of the collection of mundane attempts to regulate, codify and render legible the increasingly complex and crowded cities of the nineteenth and twentieth century. ${ }^{67}$ Unlike the priorities of the preservationists, these were quotidian, entwined issues of urban governance and local finance that recognised the interplay between the fundamentally economic nature of urban space and the desire to regulate that very space.

\section{IV}

\footnotetext{
63 'Derating advertising hoardings', 16 Feb 1931, NA/HLG/56/1116.

${ }^{64}$ Sheldon, History of poster advertising, p. 223.

65 'LCC and rating of advertisements', Times, 14 Apr 1932, p. 8.

66 'Correspondence: G.R.Coles to Street', 2 Aug 1957, NA/HLG/71/1738.

${ }^{67}$ See for example Leif Jerram, Streetlife: the untold story of Europe's twentieth century (Oxford, 2010), ch.5; Patrick Joyce, The rule of freedom: liberalism and the modern city (London, 2003) ch.1 \& 2 .
} 
Although the early part of the twentieth century had seen considerable activism by local corporations, central government remained unconvinced of the need for significant regulation in urban areas. Viscount Birkenhead, the Lord Chancellor, typified the opposition to greater control during the 1920 s when he 'overwhelmed with ridicule' several proposed advertising bills, arguing that further powers were 'futile and unnecessary'. ${ }^{68}$ The $1907 \& 1925$ ARAs, and the 1932 T\&CPA contained provisions to create byelaws to control advertisements in areas of high amenity, but attempts to pass clauses controlling advertisements in all areas were rejected. Instead, model clauses produced by Halifax, Farnworth and Otley, that only prohibited billboards larger than twelve feet in height, became the norm. However, restrictions on size simply matched the limits of the industry standards and these early acts changed very little. ${ }^{69}$ As the LCC and many others discovered when proposing byelaws under the 1907 Act, central government was opposed to the use of the legislation to establish anything resembling a blanket system of billboard licencing. ${ }^{70}$ Indeed, even rural authorities found the legislations of limited use. In 1927, this time under the 1925 revisions, Cumberland County Council's proposed byelaw prohibiting roadside advertising without permission across the county were rejected by the Home Office. ${ }^{71}$ In 1936 Surrey Country Council's attempt to pass a similar byelaw under the 1932 T\&CPA was again stymied by opposition from both parliament and the BPAA, who both agreed that not all of the area was of sufficient amenity value. ${ }^{72}$

Even though local government activism increased during the interwar period, there was little uniformity in their motivations before the mid-1930s. Rotherham's regional plan of

\footnotetext{
${ }^{68}$ Hansard, HL Deb, 08 May 1923, vol.54, cc.8-20.

${ }^{69}$ Moran, The business of advertising, p. 146-51.

70 'Letter to Hampstead Town Clerk', 27 Mar 1915, NA/HO/45/17318.

71 'Letter from Cumberland County Council', 12 Oct 1932, NA/HO/45/16607.

72 'Surrey County Council bill', undated 1936, NA/HO/45/16677.
} 
1925 saw adverts as an aesthetic problem in rural setting, but also positioned advertising as threat to efficient flows of traffic:

There can be little controversy as to the need for the control of the many varieties of advertising signs which in certain places are disfiguring the countryside....A matter likely to be of more importance however in the Rotherham Region is the growing tendency to utilize every important road junction for advertisement purposes, so that more legitimate direction boards and distance posts are apt to be missed. ${ }^{73}$

This type of sentiment exemplified the development of governmental thinking about advertising, harking back to the nineteenth century impulse to remove impediments to free circulation, but also hinted at the emergence of the ordering schemes that would come to characterise post-war planning. Nevertheless, thinking about advertising was, as yet, far from uniform and six years later in Sheffield's regional plan, though adverts were listed as 'unmitigated nuisances' to the countryside, the authors Patrick Abercormbie and T.H. Johnson still allowed that 'advertisements may be attractive objects in the urban scene. ${ }^{, 74}$

By the 1930s, though, corporations and councils were beginning to change the way they conceived of advertising's impact. In 1930, in an exceptional case, Liverpool managed to gain complete licencing control over all advertisements through section 29 of their corporation bill. That this bill was passed into law despite the objections from the Secretary of State and the BPAA was certainly unusual, but Liverpool Corporation's reasoning is of most note. In their opinion, the remedies available to them under the existing acts of 1907 and 1925, though adequate to protect the amenity of historic and architecturally valuable areas, were insufficient to control advertising in residential areas. ${ }^{75}$ The insistence that residential areas had intrinsic amenity value to the inhabitants departed from the narrative of SCAPA, the advertising companies and central government and signalled a template for future local

\footnotetext{
${ }^{73}$ William Davidge, The Rotherham regional planning scheme (Rotherham, 1925), p. 102.

${ }^{74}$ Patrick Abercrombie \& T.H. Johnson, Sheffield and district regional planning scheme (Liverpool, 1931), p. 54.

75 'Supplementary report of the Secretary of State for the Home Department on the Liverpool Corporation Bill (No.2), 1930’, 28 Apr 1930, NA/HLG/54/264.
} 
government objections to advertising. This tendency was again on display in 1933 when, in support of Salford Corporation's bill seeking similar powers to Liverpool, Conservative MP for Salford West, Fred Astbury argued:

The chief opposition to the Bill comes from the bill posters...they want to post their bills on every gable-end and on the front of every cottage in the poorer parts of Salford. I say that the poor people in those districts have as much right to protection and to have a pleasurable outlook on life as we have in the better districts...for years these poor people have complained to me that what little outlook they have has been spoiled by these hideous advertisements. ${ }^{76}$

Like Liverpool's arguments, his defence of the bill exemplified the growing opinion amongst local authorities that, regardless of the subjective aesthetic appeal of an area, large amounts of any advertising in residential neighbourhoods negatively affected people's self-perception.

This change in how local government was thinking about billboards and posters was in even greater evidence towards the end of the Second World War, as attitudes to advertising coalesced into something more coherent within the language of town planning. When Sheffield again produced a plan for urban redevelopment in 1945 they stated:

Our attempt to achieve architectural amenity, however, involves more than the provision of well designed new buildings. The creation of beauty calls also for the destruction of ugliness, whether it be in existing buildings, advertisements, in flashing signs, in hoarding in park railing or evening our street lamp-posts. ${ }^{77}$

The two emerging strands of the debate over outdoor advertising traded in the general rights of citizens to order and dignity in the urban environment. Yet there is scant evidence that advertising control was ever of more than passing interest to the public. In 1944 Mass Observation found that only $14 \%$ of people objected to advertising of any sort and an even smaller proportion of this group, mostly middle-class individuals, had specific objections to hoardings as a disfiguring presence in the city. ${ }^{78}$ Instead, what was shaping the language of advertising control were the philosophies of comprehensive redevelopment that emerged

\footnotetext{
${ }^{76}$ Hansard, HC Deb, 27 July 1933, vol.280, cc.2869-912.

${ }^{77}$ Sheffield Town Planning Committee, Sheffield replanned (Sheffield, 1945), p. 62.

${ }^{78}$ MOA, Public Attitudes to Advertisements, Feb 1944, p. 5.
} 
during the period. Although arguably a process that began in the 1920s and 1930s, the three decades that followed the Second World War were the most adventurous and eventful period of town planning in Britain. ${ }^{79}$ At the core of so much of the thinking about planning either side of the Second World War were the broad philosophies characterised by historians as 'urban modernism'. ${ }^{80}$ This was an approach to comprehensive redevelopment, which held that urban environments should be organised with as great a sense of order and uniformity as possible, either in the planning of new areas or the regulation of existing ones. Furthermore, planners contended this process of regulation, control and ordering would have profoundly positive effects on the quality of citizens' lives, their happiness, community spirit and ultimately society as a whole.

Urban modernism is not important here because of the architecturally Modernist designs that were its hallmarks during its 1960s zenith, but because its ideas of organisation and function were fundamental to over three decades of even the most seemingly insignificant municipal decision making. The broad collection of approaches to governance called urban modernism conditioned everything from the layout of vast estates of social housing and gleaming new shopping centres, to the tediously mundane introduction of clean air laws, the regulation of building heights, residential planning permission, the colour of garage doors, and here the control of outdoor advertising. ${ }^{81}$ What the following discussion suggests is that tying these disparate projects together was not a vague idea that uniformity led to functionality, nor merely the still-visible notions of liberal governmentality that saw

\footnotetext{
${ }^{79}$ Bullock, Building the post-war world; Gordon Cherry, Cities and plans: the shaping of urban Britain in the nineteenth and twentieth Centuries (London, 1988); Gold, The experience of modernism; John Gold, The practice of modernism: modern architects and urban transformation, 1954-1972 (London, 2007); Otto Saumarez Smith, Boom cities: architect planners and the politics of radical urban renewal in 1960s Britain (Oxford, 2019); John Stevenson, 'Planners' moon? The Second World War and the planning movement', in H.L. Smith, ed., War and social change: British society in the Second World (Manchester, 1986), pp. 58-77 (pp. 59-60).

${ }^{80}$ Gunn 'The rise and fall of British urban modernism'; Guy Ortolano, Thacther's progress: from social democracy to market liberalism through an English New Town (Cambridge, 2019), p. 20.

${ }^{81}$ Greenhalgh, Reconstructing modernity, passim.
} 
regulated space as shaping citizens' 'direct moral self-control' ${ }^{82}$ Instead, urban modernism, at least in the period studied here, encapsulated the notion that engendering feelings of positive self-perception, local identity, dignity and pride through an ordered and pleasant environment was itself a tool of governance central to creating a more functional city. Outdoor advertising was a direct challenge to these notions because it was an uncontrolled, unplanned and decidedly commercial aspect in the residential environment, and a threat to the supposed experiential benefits they brought. ${ }^{83}$

What created the possibility that these new approaches to urban space might succeed was the formulation a group of acts that governed housing, planning and, importantly here, outdoor advertising, during the interwar period. The 1923 Housing \&c. Act allowed that schemes could be made to preserve 'areas' with 'special architectural, historic or artistic interest attaching to a locality' with 'a view to preserving the existing character' which included the 'area prescribing the space about buildings' ${ }^{84}$ Near identical provisions were also included in the 1925 Town Planning Act and the 1932 T\&CPA allowed the restriction of outdoor advertising in new and extant areas where local 'amenity' might be prejudiced by billboards and posters. ${ }^{85}$ The 1931 Ancient Monument Act, in a similar spirit, allowed for the creation of special areas to 'preserve the amenities' of any ancient monument by restricting development in the locality. ${ }^{86}$

In embryonic form these pieces of legislation held the possibility of creating what would become 'conservation areas' and contained the seed of the idea that would, by long

\footnotetext{
82 Joyce, The rule of freedom, particularly p. 86-90.

${ }^{83}$ Baker, 'Public sites versus public sights, pp. 1187-213; Iveson, 'Branded cities', pp. 151-74.

${ }^{84}$ Housing Act, 1923, (13 \& 14. Geo. 5. c.24), s.23.

${ }^{85}$ Town Planning Act, 1925 (15 \& 16 Geo. 5, c. 16), s.1(2); Town and Country Planning Act, 1932 (22 \& 23 Geo. 5. c.48).

${ }^{86}$ Ancient Monuments Act, 1931 (21 \& 22 Geo. 5. c.16).
} 
means, become 'heritage setting'. ${ }^{87}$ However, what they also did was encapsulate a growing belief that successful planning involved the control of the visual environment with a view to the entire experience of an area's character, or more properly its 'amenity'. Nevertheless, during the interwar period, this emerging planning framework remained focused upon aesthetically pleasing areas, and little case could be made under the prevailing interpretation of amenity to limit advertising in existing residential areas. Even under the 1932 T\&CPA, which did allow local authorities to object to advertising in certain areas, the framing of the law meant that courts had to adjudicate on disputes over amenity between advertisers and local government. In these instances, judgements almost always fell on the side of the advertisers because the judiciary tended to see little amenity value in ordinary urban areas. ${ }^{88}$ Interpretation of amenity was thus the shoal upon which local authorities attempts to regulate advertising floundered. It remained a vague term and, though well intentioned, the suite of laws proved unsuitable to regulate extant and quotidian environments.

\section{V}

The interpretation and usage of the term 'amenity' was thus critical to how outdoor advertising might be controlled and to attempts to create order and uniformity in the visual environment. 'Amenity', or more likely 'amenities', are familiar words to most people, typically referring to public facilities such as shops, bus stations, parks or playgrounds. However, in town planning legislation amenity has a legally significant, but vague meaning, interpreted as anything 'from an essentially negative restriction against nuisances to a distinctly positive notion of visual delight' ${ }^{89}$ In the post-war period, because it was enshrined

\footnotetext{
${ }^{87}$ For definitions see: Historic England, The setting of heritage assets ( $2^{\text {nd }}$ edition), online resource https://historicengland.org.uk/images-books/publications/gpa3-setting-of-heritage-assets/heag180-gpa3-settingheritage-assets/ accessed 19 Dec 2019.

88 Town and Country Planning Act, 1932, (22 \& 23 Geo. 5. c.48), s.47(1), as noted in Barry Cullingworth and Vincent Nadin eds., Town and country planning in the UK (London, 2002), p. 144.

${ }^{89}$ Donald L. Foley, 'British town planning: one ideology or three?', The British Journal of Sociology, 11:3 (1960), pp. 211-31 at p. 220. Also: Philip Booth, 'Planning and the rule of law', Planning Theory and Practice, 17:3 (2016), pp. 344-60 (pp. 354-6).
} 
in almost every piece of law governing planning passed since 1907, amenity became one of the 'most relied-upon concepts in British town planning' referring to 'a quality of pleasantness in the physical environment' that was widely seen as the central objective of planning. ${ }^{90}$ Furthermore, its dualistic nature - at once almost entirely devoid of meaning, whilst intrinsic to what might be legally allowable in a given space - made it a key conceptual battleground for planners and local corporations attempting to regulate urban space. As Katrina Navickas has shown, in arguments over rural landscape preservation during the 1950s, debates often hinged on interested parties' attempts to map a range of meanings including economic function, citizen's experience and aesthetics onto amenity. ${ }^{91}$ Whomever could control how amenity was interpreted in a formal sense could deploy arguments for its maintenance in the pursuit of their aims. The problem, at least for local government, had been that before the Second World War, the way amenity was interpreted by central government and the judiciary had firmly favoured the definitions of the advertisers.

The 1947 T\&CPA contained powers that hinged on interpretations of amenity, because it allowed local authorities to create areas of special control - including all new developments - prohibit any advertisement that prejudiced amenity, and - in what would prove to be a crucial addition - made the Minister the final point of appeal for disputes. ${ }^{92}$ In effect, the only areas in which local authorities could not wield arbitrary control of outdoor advertisements after 1947 were extant locations were amenity value might be contested by advertisers. Yet, with no real prospect of genuinely holistic rebuilding of cities possible during the austerity and shortages of the decade following the war, local corporations' desire to regulate their towns and cities fell specifically on these very types of location. ${ }^{93}$ Advertisers' organisations

\footnotetext{
90 'British town planning', p. 220.

${ }^{91}$ Katrina Navickas, 'Conflicts of power, landscape and amenity in debates over the British Super Grid in the 1950s’, Rural History, 30:1 (2019), pp. 87-103

${ }^{92}$ Town and County Planning Bill 'B', 17.1.1, clause 28, undated c. Jan 1947, NA/HLG/71/1045.

${ }^{93}$ On the difficulties of immediate post-war redevelopment see: Junuchi Hasegawa, Replanning the blitzed city centre: a comparative study of Bristol, Coventry and Southampton (Buckingham, 1992); Peter J. Larkham,
} 
in England and Scotland, showing considerable prescience, objected during the initial passage of the new bill to the Minister having final say over disputed cases, pushing to maintain the interpretive role of the courts that had proven useful to them under the 1932 legislation. ${ }^{94}$ Lewis Silkin, the Minister for Town and Country Planning, however rejected these concerns out of hand, assuring advertisers that no Minister would deal unfairly with any future judgements. ${ }^{95}$

In furtherance of their desire to establish more holistic systems of control in residential areas, upon the T\&CP bill becoming law local authorities began to push at the boundaries of what types of areas had sufficient amenity value to preclude outdoor advertising. ${ }^{96}$ In 1948 Manchester Corporation refused permission for a gable-end billboard in a slum-clearance area, stating that they had 'always striven to avoid gable-end advertisements, which [we] considered to be definitely detrimental, especially to the amenities of a residential area' ${ }^{97}$ Outdoor advertising company Arthur Maiden disputed the amenity of the location, noting that the area was 'one of the poorer neighbourhoods', adding that 'the erection of an advertising position ... would improve the amenity of this area' ${ }^{98}$ In this instance Silkin ruled in favour of the advertisers, he too judging that the area had little amenity to be protected. Indeed, despite pressure from local corporations, Silkin remained demonstrably on the side of the

\footnotetext{
'Thomas Sharp and the post-war replanning of Chichester: conflict, confusion and delay', Planning Perspectives 24:1 (2009), pp. 51-75; Nick Tiratsoo, 'The reconstruction of blitzed british cities, 1945-55: myths and reality', Contemporary British History, 14:1 (2000), pp. 27-44.

94 'Meeting with representatives of the Scottish poster advertising industry', 21 Feb 1947; 'Control of advertisements: fourth meeting of committee "A", 27 Mar 1947, NA/HLG/71/1045.

95 'Draft of speech to the British Poster Advertising Association' by Silkin, 17 June 1947, NA/HLG/71/1045.

96 The relevant section dealing with the role of the Minister in deciding outdoor advertising appeals appears in regulation 20(4) of the Town and Country Planning (Control of Advertising) Regulations (S.I. 1948 No.1613) that was appended to the original T\&CPA 1947.

97 'Appeal Hearing', 26 January 1949, NA/HLG/79/421.

98 'Letter to the MoT\&CP', 19 Nov 1948; 'Letter to Arthur Maiden Ltd from Town Clerk', 9 Nov 1948, NA/HLG/79/421.
} 
advertising companies, stating in 1949 that if 'there is any doubt we give the applicant [the advertiser] the benefit of the doubt' ${ }^{99}$

Gable-end advertising was of particular concern to corporations as it tended to be sizeable, was hard to remove and was, by its nature, prevalent in residential areas [see Fig.3]. In 1950 the AMC asked the Ministry to review its own approach, which the AMC contended viewed gable end advertising 'of a reasonable size [as not] prejudicial to amenity', even in areas with 'residential elements'. The AMC added that gable-end advertising was 'one of the most obnoxious forms of advertising' and that it was a practice that was 'not consistent with good and orderly planning.' The display of advertisements on gable ends, they concluded, 'inevitably accelerate[d] the deterioration' in districts that had either already 'begun to deteriorate' or did not 'possess high amenity value' in the first place. ${ }^{100}$ The AMC framed their objections in the increasingly common language of holistic planning, but they also implied how important the perception of an area was to prevent it 'deteriorating'. The Ministry, though, remained unsympathetic, believing that 'advertising must be treated as an accepted feature of ordinary economic life', and there should be a good reason for refusing... applications to display advertisements'. They added that authorities needed to focus on 'visual amenity' and not a broader definition of 'psychological amenity', adding that they must consider the actual amenity of an area, rather than enforcing a blanket ban on gable-end advertising. ${ }^{101}$

Whilst it is clear that economic necessity was a motivating factor for central government, local authorities had never suggested that advertising had no place in their cities at all. Instead, the material of these disagreements was over how advertising affected the experience of residential areas and the perceptions of inhabitants. The Ministry's distinction

\footnotetext{
99 'Silkin tells sign men of outdoor law clean-up', World's Press News and Advertisers' Review, 31 Mar 1949, p. 4.

100 'Meeting between AMC and Ministry', 4 May 1950, NA/HLG/79/1723.

101 'Memo from Mr Price-Jones to Mr Proper', 1 Dec 1949, NA/HLG/79/172.
} 
between psychological and visual amenity, whilst vague, suggests that their notions of amenity were still firmly rooted in ideas of more discernible aesthetic value. In contrast, just like Liverpool and Salford in the 1930s, the corporations of the post-war framed the commercialisation of residential space as an issue because it degraded the self-perception of their citizens through their everyday encounters with outdoor advertisements. Whilst, as Baker has argued, outdoor advertising ‘destabilised architectural and landscape design's power to properly form cities and citizens', post-war corporations and councils were also fighting over largely working-class areas with little accepted architectural or aesthetic merit. ${ }^{102}$ Their position represented a redefinition of amenity that positioned the concept not as an exceptional element that enhanced ordinary experience, but an ever-present aspect of all environments that should be maximised. Just as Katrina Navickas has shown that questions over the rights of working-class citizens to enjoy rural landscapes revolved around how sufficient levels of amenity value might be determined, the arguments between the government, advertisers and local corporations here show a similar process of contestation framed by the language of class prejudice and citizen's rights. ${ }^{103}$

In these initial clashes following the introduction of the 1947 T\&CPA, it is tempting to see the apparent championing of citizens' right to neighbourhoods free from commercial intrusion as evidence of a post-war social-democratic state at work. That, as Todd argues, in this period working-class people's 'interests were the state's primary priority' in urban development, however imperfectly executed. ${ }^{104}$ Certainly, much of the evidence here is framed in this type of sentiment: as Sheffield's Cllr. Wood pointed out, the Ministry often felt advertisements were suitable in 'mixed areas [of industrial/commercial and residential use] so prevalent in northern towns'. ${ }^{105}$ Yet, any such explanation needs to be tempered by the

\footnotetext{
102 Baker, 'Public sites versus public sights', p.1197.

${ }^{103}$ Navickas, 'Conflicts of power', p.95.

104 Todd, 'Phoenix rising', p.702.

${ }^{105}$ Notes on meeting between Ministry and AMC', 4 May 1950, NA/HLG/79/1723.
} 
consideration of local authorities' longer-term activism against uncontrolled advertising and the further hardening of the stance of the Ministry against advertising under the incoming Conservative government. Yet, it is clear from corporations' rhetoric concerning class and inhabitants' rights that a significant change was occurring. Just as the regulators of Victorian streets had seen the self-conscious freedom of the individual as part of the means to regulate their cities, here, I suggest, local corporations recognised a type of social-democratic subject - rhetorically conscious of their own rights to and the state's obligation to provide the greatest possible dignity and pleasantness in their everyday lives and environments - as the central object of their plans.

The presence of a general discourse concerning the rights of this 'social-democratic' subject thus helps explain how advertising control progressed regardless of the identity of ministers or the party in power. The beginning of the 1950s saw the replacement of Lewis Silkin with Hugh Dalton and the new Minister saw advertising in residential areas differently to his predecessor. In $194960 \%$ of appeals to the Ministry were upheld, yet by the end of 1950 this fell to $23 \% .^{106}$ Indeed, Dalton made it clear that any future decisions would lean more towards local authorities from the outset, signalling as much his support for local government as any strong views on advertising. ${ }^{107}$ Though Dalton might claim that there would be no 'violent and sudden change in the trend of decisions', civil servants estimated that the number of appeals allowed would fall to less than $8 \%$ and faced censure when they objected. ${ }^{108}$ By late summer, the Advertiser's Weekly argued that 'control [was] becoming repression' whilst local authorities' application of advertising legislation 'stretch[ed] beyond reason any interpretation of amenity'. ${ }^{109}$ In spring 1952, whilst the advertising companies

\footnotetext{
106 'Parliamentary question to Mr Dalton', 27 Feb 1951, NA/HLG/71/1723.

107 'Control of outdoor advertisements directive on future administration'(from Dalton), 25 May 1950, NA/HLG/71/1738.

108 'Control of advertisements - principles governing appeal decisions', 16 May 1950 and 'Control of Advertisements', 27 May 1950, NA/HLG/71/1738.

${ }^{109}$ Advertisers Weekly, 'Control becoming repression?', 24 Aug 1950, p.1.
} 
beseeched the Ministry that 'amenity was never meant to cover some of the places' where they had sided with local authorities, P.D. Coates representing the Ministry of H\&LG signalled the considerable transformation in central government opinion. 'The Department', he stated 'could in no circumstances accept that because people unfortunately enjoyed little amenity in their surroundings what amenity there was did not deserve protection' ${ }^{110}$

The interpretation of how amenity related to individuals' experience of where they lived had thus become the defining issue in advertising appeals, and central government was gradually beginning to accept local authorities' views. In 1953, for example in clarifying their decision on a site of mixed residential and commercial property near a railway yard in Crown Street, Liverpool - a spot where advertising had been licenced in 1947 under the 1930 Liverpool Corporation Act - the new Minister, Harold Macmillan, ruled that any advertising would be 'out of keeping with the residential character... and prejudicial to amenity' commenting particularly on the proximity of a group of 'pleasing' interwar flats. The advertising company complained that the flats had been there in 1947, and that with an 'industrial background... a poster panel of the type proposed could not but produce a pleasing relief to the existing drab and unsightly outlook'. ${ }^{111}$ This notion - that advertising might improve an area - was, however, now finding a less sympathetic audience than is had done in the earlier years of the century. In actuality, it became increasingly apparent that even the slightest possibility of an advertising station being visible from a dwelling was enough to reject it. In 1955 in Price Street, Birkenhead, despite there at the time being no residential properties, the Ministry rejected an appeal from advertising company David Allen \& Sons, on the grounds that proposed future slum clearance might make any hoardings visible from local people's homes. Again, the advertiser's arguments that given the 'present drabness of this

\footnotetext{
110 'Correspondence: P.D. Coates to J.D. Jones, 28 May 1952, NA/HLG/71/1062.

111 'Site at Crown Street, Liverpool', Ref:1324/40030/361, 6 June 1953, NA/HLG/71/1733.
} 
site...far from constituting any offense to amenity, the advertisement panels [would] relieve the existing harsh outlook' left the Ministry officials unmoved. ${ }^{112}$

In Jarrow in 1955 the local authority, in successfully objecting to an appeal, articulated a position that showed just how significantly attitudes had changed since 1948. After alluding to the damage to the amenity of nearby houses, and despite the advertiser's offer to beautify the spot with a paved forecourt and seating, they added that 'the time has arrived when a halt must be called to the display of advertisements in the Borough'. ${ }^{113}$ The baldness of the desire to regulate all advertising contrasted sharply with the conflicts with the Ministry of the late 1940s and showed the confidence the council now had that its decisions would be viewed favourably by the Ministry. What it also demonstrated was the way that the more practical aims of local authorities had been achieved. Advertising control may well have simply been a new variation on the desire to regulate the built environment begun in the nineteenth century, albeit one enlarged in complexity and ambition. However, the way the ordinary citizens' experience was positioned at the heart of the arguments here points to the manner in which the notions of social democracy were themselves being co-opted into the tool box of governmentality. The post-war citizen had a right to enjoy a built environment that was as orderly and enjoyable as possible, an environment in which amenity was maximised by the elimination of disruptive sensory intrusions. In fighting to redefine what amenity meant, local authorities demonstrated their commitment to the urban modernist visions of holistic uniformity in planning that dominated the period, but did so in a deeply pragmatic and municipal manner. This was an approach that was ideologically consistent with, but physically quite unlike the grand redevelopment schemes that have attracted greater historical attention. In a certain sense, amenity itself, though crucial to the highlighted disputes, was

\footnotetext{
112 'Site at Price Street Birkenhead', Ref:954/40030/76, 27 June 1955, NA/HLG/71/1733.

113 'Site at 100/104 High Street, Jarrow', Ref:1265/40030/12, 19 Jan 1955, NA/HLG/71/1733.
} 
never really redefined in a meaningful way. Instead, the disputes hinged largely over where amenity existed, not what it was. The importance of amenity lies in understanding it as a concept with legal weight that local authorities and planners could contest and apply to make concrete their own agendas. Yet at the same time the way that amenity was debated here reveals the ways that, in the middle of the twentieth century, local authorities were imagining the experience and self-perception of the ordinary citizen as central to their strategies of urban governance.

\section{VI}

In many ways the change of attitude towards outdoor advertising during the 1950s was the culmination of a process that had begun over a century earlier, a process that tracks the development of strategies of governmentality and the importance of local authorities in driving somewhat overlooked, but nevertheless important changes in the urban environment. Outdoor advertisers had attempted to keep pace with the changing attitudes to their practices, but even before the 1962 T\&CPA codified restrictions on shop-front signage that became known as the 'Anti-clutter Code', both their attempts at self-regulation and perceptions of advertising's place in the urban environment were lagging behind the prevailing opinion in central and local government. ${ }^{114}$ It is quite challenging for the contemporary mind to envisage just what the laxer restrictions on advertising allowed in urban centres and even rural roads before the Second World War, but the curtailing of outdoor advertisements in the 1950s represents a radical definition of the visual environment of towns and cities. It is testament to how effectively outdoor advertising was ultimately controlled in most areas that the significance of the processes discussed in this article have been largely overlooked by

\footnotetext{
${ }^{114}$ Properly, the Code of Standards for Advertising on Business Premises introduced by the Incorporated Society of British Advertisers, removed c. 73,000 signs by 1962 and, with the new law a further c.430,000 by 1970. Hansard, HC Deb, 9 Mar 1962, vol.655, cc.767-843; History of Advertising Trust Chronology, online resource https://www.hatads.org.uk/documents/Chronology.pdf accessed 20 Aug 2019.
} 
historians of urban planning and local government. The recent nostalgia for 'ghost signs', that has seen tour groups guided through an urban past that now seems quaintly alien to the twenty-first century citizen, speaks to the success of advertising control,.

On one hand the purpose of this article has been to examine the varying motivations that animated the crucial actors who contributed to this change in the urban environment. In illustrating this it has acted as a both a prelude and a coda to the very limited number of studies of outdoor advertising control, which have tended to begin and end their analysis with the achievements of SCAPA. On the other hand, advertising control us just one of a host of case studies that have the potential to show how the developing priorities of local government fit into wider histories of spatial governance. Local government pushed outdoor advertising control as a facet of their own evolving approaches to the control and regulation of the spatioeconomic fabric of their towns and cities. In this sense, outdoor advertising control tracks the changing ways that local government has approached urban space since the early nineteenth century. First, in encountering advertisements as a very physical and disruptive element of the sprawling, disordered cities, local authorities sought to establish statutory controls that tidied the material nuisance of hoardings, billboards and posters as part of regimes and codes that promoted free circulation and an uncluttered city as a tool of urban governance. Secondly, before the interwar period outdoor advertisements, particularly billboards were generally an accepted part of the economic functions of urban environments. Rural councils and corporations with picturesque architecture or historical buildings did seek to curtail advertising excess in aesthetically important locations, but the principal concern for most local authorities lay in basic regulation, separating out rateable values and in how to maximise their income from advertising stations. Finally, beginning in the 1930s, but reaching its zenith towards the end of the 1940s and early 1950s, the last stage of outdoor 
advertising control covered here demonstrates the redefinition of approaches to space characteristic of post-war planning and urban modernism.

Historians of town planning in the inter and post-wars have, understandably, tended to focus their attention on newly created elements of the built environment. Yet for most local corporations and councils the greater part of their jurisdictions were occupied by extant spaces that had no immediate prospect of change before the late 1950s, if ever. Spaces in which they nevertheless wished to apply the same logics of spatial governance that characterised the new housing estates, tower blocks and shopping centres they created elsewhere. Central to these notions was the control of the visual environment as a way of regulating experience at street level and the importance of citizens' perceptions of their environment. As a result, understanding the enthusiasm and dynamism of local authorities' attempts to control outdoor advertising, centred around the notion of amenity, reveals both the totalising visions of urban modernism and the centrality of regulating and shaping citizens' experience to these ideas. In contesting how amenity might be applied, if rarely how the term itself might be understood, local planners and their corporations plotted citizens' experiences, notions of selfhood and self-worth as a crucial factor in the benefits of regulated and planned environments. Indeed, this was despite scant evidence that there was much interest in advertising control amongst the public in any period. The rights of, what I have here - admittedly with a slight sense of terminological unease - termed, the 'social democratic' subject, were nevertheless placed at the heart of the urban modernist project to create working cities. The attempts to control advertising were thus about much more than ugliness or the exploitation of rateable value - although these are important - they were a product of a belief that uniformity and visual control was an essential component in producing cities that were more orderly and functional. This was not the high, aesthetic modernism that would become so evident in the striking buildings of the 1960s, but a quiet 
radicalism concerned with the shaping the deeply practical and everyday aspects of citizens' lives and experience that was central to the practices of municipal government during the post-war period. 